\title{
Monoamines and neuropeptides in Bryozoa: localisation and possible functions
}

\author{
K.V. Shunkina, O.V. Zaitseva \\ Zoological Institute RAS, Universitetskaya emb. 1, St.Petersburg, 199034 Russia. E-mails: \\ keyelastic@gmail.comovzaitseva@inbox.ru
}

ABSTRACT: Recently many data on distribution of common neuromediators in different bryozoan species were published. Based on the three species of freshwater bryozoans, we compare our results with those from other studies in attempt to understand possible role of each neuromediator (serotonin, FMRFamide, catecholamine) in the nervous system of Bryozoa. Serotonin appears to be responsible for feeding behavior and digestion, FMRFamide mainly participate in the muscles innervation and catecholaminergic cells could be mechanoreceptors.

How to cite this article: Shunkina K.V., Zaitseva O.V. 2017. Monoamines and neuropeptides in Bryozoa: localisation and possible functions // Invert. Zool. Vol.14. No.1. P.67-72. doi: 10.15298/invertzool.14.1.10

KEY WORDS: bryozoa, nervous system, FMRFamide, neuromediators, serotonin, catecholamine, Lophotrochozoa.

\section{Моноамины и нейропептиды у мшанок: локализация и возможные функции}

\author{
К.В. Шунькина, О.В. Зайцева
}

Зоологический институт РАН, Университетская наб., 1, Санкт-Петербург, 199034 Россия. e-mails: keyelastic@gmail.comovzaitseva@inbox.ru

АННОТАЦИЯ: В последнее время было опубликовано множество данных о локализации широко применяемых в научных исследованиях нейромедиаторов. Мы сравнили результаты, полученные для трех видов пресноводных мшанок с другими исследованиями с целью выявления возможной роли каждого из исследованных нейромедиаторов (серотонина, FMRFамида, катехоламинов) в нервной системе мшанок. Оказалось, что серотонин в первую очередь отвечает за пищевое поведение и пищеварение, FMRFамид участвует в иннервации мускулатуры, а катехоламинергические клетки являются механорецепторами.

Как цитировать эту статью: Shunkina K.V., Zaitseva O.V. 2017. Monoamines and neuropeptides in Bryozoa: localisation and possible functions // Invert. Zool. Vol.14. No.1. P.67-72. doi: 10.15298/invertzool.14.1.10

КЛЮЧЕВЫЕ СЛОВА: мшанки, нервная система, FMRFамид, нейромедиаторы, серотонин, катехоламин, Lophotrochozoa. 


\section{Introduction}

Bryozoans are small colonial filter-feeding invertebrates, common in the freshwater and marine habitats. They form bushy, arborescent or sheet-like colonies, attached to the different types of the substrata. Three bryozoan classes, Gymnolaemata, Stenolaemata and Phylactolaemata differ much in their life pattern, morphology and habitat. Thus, the largest class Gymnolaemata is predominantly represented by marine species with calcified cystid wall and a small bell-shaped tentacle crown (lophophoreretractile filter-feeding apparatus). Stenolaemates are exclusively marine, with calcified cystid and bell-shaped lophophore. Phylactolaemates are freshwater bryozoans, with chitinous or gelatinous cystid wall, and predominantly having horseshoe-shaped lophophore (Hyman, 1959).

For a long time there was a lack of data on bryozoan (or other lophophorates) nervous system. But after CLSM became a routine technique the situation began to change, and a number of studies on phoronids, brachiopods and bryozoans have been published. Most of them offer only a high resolution description on different neuromediator localisation in certain species.

In this paper we generalize the data concerning elements of the bryozoan nervous system with different neuromediator activity such as 5HT-, FMRFamide- and catecholaminergic. Comparing our data with the published results we discuss the possible functions of these neuromediator.

\section{Materials and methods}

Our study is focused on three species of freshwater bryozoans - Cristatella mucedo, Plumatella repens and Fredericella sultana. Every species has some unique morphological traits: while colonies of $P$. repens, similar to the most bryozoans, are attached to the substrate, colonies of $C$. mucedo have a special organ called "sole" and are able to move throughout all their life; colonies of $F$. sultana has the smallest polypide among freshwater bryozoans which has a bell-shaped lophophore which is uncommon for freshwater bryozoans (Shunkina et al., 2013, 2014, 2015). To visualize different parts of the nervous system we used antibodies to common neuromediators such as 5-HT, FMRFamide and catecholamines. Staining was made by a standard protocol (described in details in Shunkina et al., 2015). As such techniques are widely used in current invertebrate neuromorphology, we have a good possibility to compare our results to literature data not only concerning other classes of bryozoans, but different lophotrochozoan animals.

\section{Results and discussion}

\section{5-HT-immunoreactive part}

5-HT-positive elements of the nervous system were found mostly in the lophophore base, tentacles and cerebral ganglion. In both, phylacto- and gymnolaemates most part of 5-HTperikariya present either in the basal part of the lophophore or tentacle base or in the proximalmost part of tentacles (Shunkina et al., 2013, 2015; Schwaha, Wanninger, 2015; Temereva, Kosevich, 2016; Serova et al., 2016). No serotonergic perikariya were found in the cerebral ganglion that has a complex 5-HT-nerve bundle (neuropil). Also small intraepithelial bipolar cells were recorded at the tips of tentacles (Schwaha, Wanninger, 2015) and at the base of the lophophore (Temereva, Kosevich, 2016). In addition, 5-HT-reactivity was seen in the special cells of the pore-complex (special structure in Gymnolaemata plugging interzooidal communication pores) (Schwaha, Wanninger, 2015). The only tentacle nerve with 5-HT-reactivity, is an abfrontal nerve (Shunkina et al., 2014, 2015, Schwaha, Wanninger, 2015). All perikariya found at the base of lophophore, tentacles or in the lower part of the tentacles in Phylactolaemates have a short peripheral sensor process in the epithelium (Schwaha, Wanninger, 2012; Shunkina et al., 2013, 2015) (Fig. 1A). The 

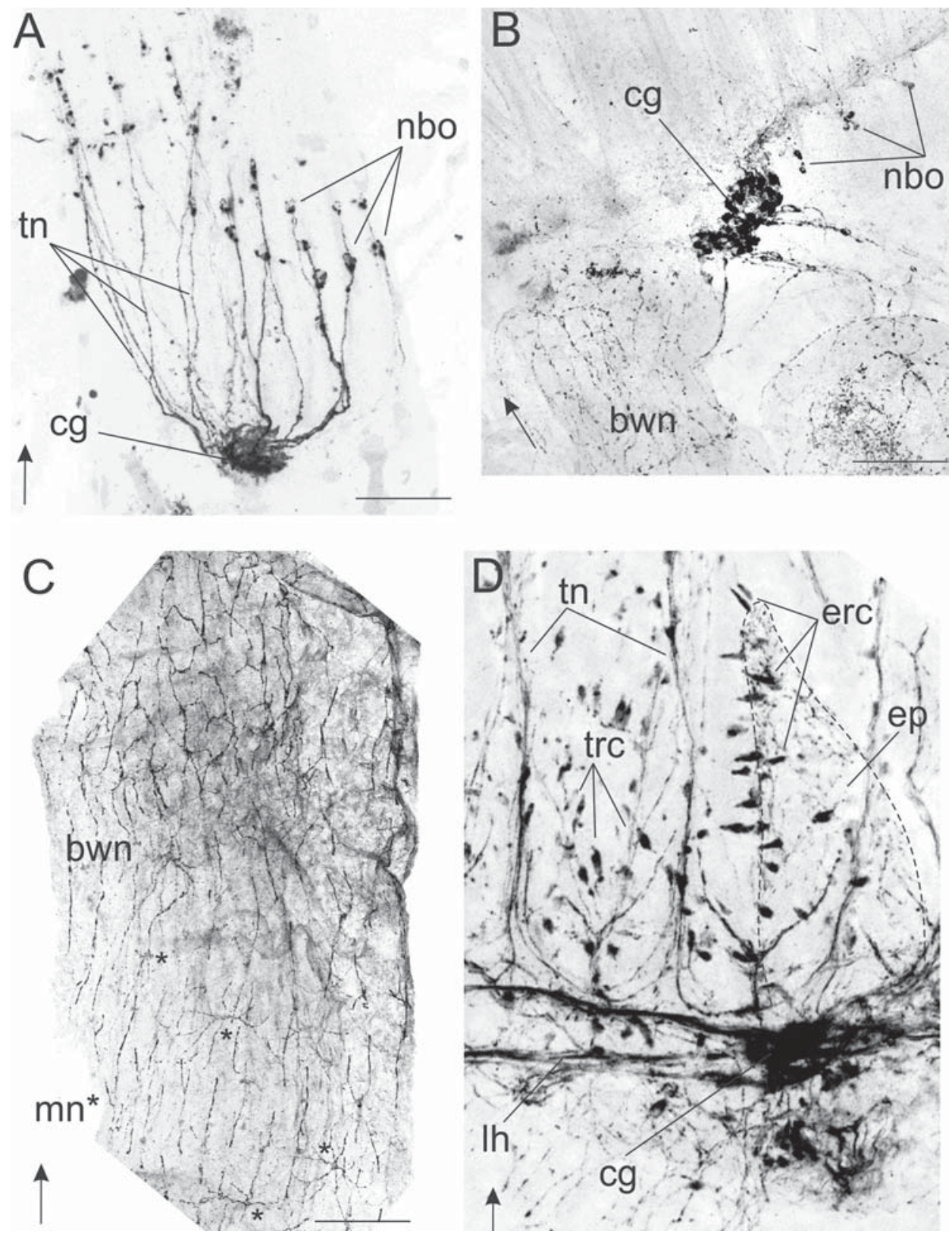

Fig.1 Different parts of freshwater bryozoan nervous system, stained with antibodies to 5-HT (A), FMRFamid (B, C) and catecholamines (D). Arrows marks the direction or oral-aboral axis. A - 5-HTpositive elements of the lophophore nervous system of Fredericella sultana. B - FMRFamidergic elements of the lophophore nervous system of Cristatella mucedo. C - FMRFamidergic receptors in the cystid wall of Plumatella repens. D - catecholamine-positive elements of the epistome (marked by a dashed line) and lophophore of Cristatella mucedo. Abbreviations: bwn — body wall nerves, cg — cerebral ganglion, ep epistome, erc - epistome receptor cells, $\mathrm{lh}$ — lophophore horns (lophophore base nerves), $\mathrm{mn}$ - multipolar neurites, tn - tentacle nerves, trc - tentacle receptor cells. Scale bar: A $-200 \mu \mathrm{m}$; B, C - $100 \mu \mathrm{m}, \mathrm{D}-$ $50 \mu \mathrm{m}$. 
same structure was also reported in Amathia gracilis (Temereva, Kosevich, 2016) (Gymnolaemata: Ctenostomata) and well seen on figures of Membranipora membranata, Palucidella articulata and some other gymnolaemates (Schwaha, Wanninger, 2015). In addition to the lophophore a cardial part of the foregut also has a 5-HT-positive innervation. Two gymnolaemates (Bicellariella ciliata and Cribrillina annulata) have an unpaired nerve extending from the cerebral ganglion down to the pharynx and then forming a nervous ring around the cardia including serotonin-positive intraepithelial cells (Schwaha, Wanninger, 2015). In the freshwater C. mucedo we described a pair of serotoninpositive nerves, extending from the cerebral ganglion to the anal part of the digestive tract (Shunkina et al., 2015).

Localization of perikarya and peripheral processes of serotonin-positive nerve cells in the epithelium could suppose their receptor function. Recently specialized polymorphic zooids were studied in the seven species of marine bryozoans. These so-called heterozooids could be represented by avicularia or vibracularia highly reduced zooid, which function is to defense the colony from predators or to clean the colony surface. Usually, the tentacle crown is reduced to a single short tentacle, and operculum (a device closing zooidal aperture) is modified into a mandibule or a setae. In spite of this modification, such heterozooids also bear a ganglion and some sensory cells. Serotoninpositive part of their nervous system is presented by a nerve bundle in the cerebral ganglion and several paired sensory cells, lying under the frontal membrane of the heterozooid. Also 5HT-positive cells were found in the tentacles of autozooids (Serova et al., 2016, 2017). Other lophophorates studied (phoronid and brachiopod) are also known to have serotonergic elements in the cerebral ganglion and lophophore (Temereva, Tsitrin, 2014, 2015).

Localization of serotonin-positive elements exclusively in the lophophore and a digestive system allows supposing that serotonin involved mostly in the feeding behavior and digestion. It corresponds the data obtained for other groups of invertebrate. Serotonin activates a feeding behavior in mollusks that begin to turn the head and tentacles and move more actively. It also intensifies movements of radula. The same effect could be attained if the mollusk is keeping hungry for a long time. Nematodes show the same patterns - after finding food, the level of serotonin increases and dumps the locomotory activity, activating the feeding process. In Hirydinea the same effect was shown: synthesis of serotonin activates the feeding activity and stops any other types of activity (see review in Dyakonova, 2012).

We assume that the serotonin-positive nerve cells which are situated in the tentacles and lophophore and under the frontal membrane of heterozooids function as chemoreceptors. After receiving a signal from serotonin-positive perikarya (warning that the food particle is inside the lophophore), cerebral ganglion activates the feeding program. Detection of the serotonin-positive perikarya in the reduced tentacle of heterozooids possibly argues for suppression of defensive behavior of autozooids in the case of feeding.

For some invertebrates presence of 5-HTpositive sensory cells was shown in the middle part of the gut (where digestion is going), and

Рис. 1. Различные части нервной системы пресноводных мшанок, окрашенные антителами к серотонину (A), FMRFамиду (B, C) и катехоламинам (D). Стрелкой указана орально-аборальная ось зооида. A - серотонин-положительные элементы нервной системы лофофора Fredericella sultana. В FMRFамидергические элементы нервной системы лофофора Cristatella mucedo. C — FMRFамидергические рецепторы стенки цистида Plumatella repens. D — катехоламинергические элементы нервной системы эпистома (обозначен пунктирной линией) и лофофора Cristatella mucedo. Обозначения: bwn - нервы стенки тела, cg — церебральный ганглий, ер - эпистом, erc - рецепторные клетки эпистома, $\mathrm{lh}$ — рога лофофора (нервы основания лофофора), $\mathrm{mn}$ — мультиполярные нервные клетки, tn - нервы щупалец, trc - рецепторы щупалец. Масштаб: A — $200 \mu \mathrm{m} ; \mathrm{B}, \mathrm{C}$ - $100 \mu \mathrm{m}$, $\mathrm{D}-50 \mu \mathrm{m}$. 
such cells are also able for exocrine secretion of serotonin inside its cavity (Zaitseva et al., 2004, 2007, 2013). Serotonin-positive cells found in the cardioesophageal ring in some bryozoans are likely to be intraepithelial receptor cells as their apical part contact the intestine internal surface. The same type of cells has been found in the digestive system of invertebrate and even vertebrate animals (although in vertebrates such cells are receptory-endocrine) (Zaitseva et al., 2004, 2007, 2013; Ovsyannikov, 2003).

\section{FMRFamide-positive part}

FMRFamide-positive elements of the nervous system were found not only in the cerebral ganglion, but also in different parts of zooids, tentacles, cystid wall. In all studied phylactolaemate Bryozoa FMRFamide-positive cells were found in the cerebral ganglion, groups of such cells could be found at the base of proximal tentacles (the number of cells in such groups vary among different species) (Fig. 1B). Groups of perikarya were found at the tentacle base in adult brachiopods (Temereva, Tsitrin, 2015). In phoronid larvae FMRFamide-positive nerves were also found in metasomal sac, midgut and tentacles. Also FMRFamide-positive perikariya were found in the apical organ of phoronid larvae (Temereva, Tsitrin, 2014). But, unfortunately, the nervous system of a larvae could not be compared with such in an adult animal, as it partly undergoes restruction during metamorphosis. In addition, in C. mucedo single receptor bipolar cells were recorded at the tip of the tentacles and FMRFamidergic innervation was detected in the musculature of the sole. Also large multipolar nerve cells were recorded in the body wall (Shunkina et al., 2015). In Gymnolaemata FMRFamide-positive cells are situated in the cerebral ganglion and at the base of the tentacles. In Arctonula arctica FMRFamidepositive receptor cells were found in the cardioesophageal nerve ring of autozooids and under the mandible, frontal membrane and in the rudimental tentacle of heterozooids (Serova et al., 2016).
Presence of the receptor cells under the frontal membrane and near the mandible in gymnolaemate heterozooids and the special form of the cells having similar multipolar processes in the phylactolaemate body wall could be an evidence that these cells are mechanoreceptive, for example, proprioreceptors (Fig. 1C). Presence of FMRFamidergic elements in the body wall, digestive system and and the musculature of internal organs is usual in many other invertebrates (see, for instance, Kotikova et al., 2002; Zaitseva et al., 2004, 2007, 2013, 2015).

\section{Catecholaminergic (CA) part of the nervous system}

At our knowledge, CA-positive elements of the nervous system were only studied in the freshwater bryozoans. It is caused by the method claims to work on alive animals, which is difficult on marine bryozoans which should be firstly decalcified. We found CA-positive cells and nerves in the cerebral ganglion, epistome (a small lobe, situated above the mouth opening in phylactolaemates), the lophophore base, tentacles and body wall (Shunkina et al., 2014, 2015). CA-positive cells situated in the epistome and the both sides of tentacles are receptors as their apical part contacts the surface. The receptory cells are intraepithelial and morphologically differently developed. More differentiated cells (located on both sides of the tentacles) show a well-developed nuclei area and peripheral sensory processes. Second type of cells (situated mainly in the epistome) are alike epithelium cells by their form and do not have a peripheral process (Fig. 1D). It could indicate that lophophore itself has more developed sensory system whereas epistome. In other invertebrates CApositive elements of the nervous system mostly present in the intestine wall (see, for example, Fominykh, 1982; Croll et al., 1997; Zaitseva et al., 2007). Being the antagonists of serotonin (in terms of behavior) CA could activate the protective behavior in invertebrates (Dyakonova, 2012). Thus, the possible function of CA-positive cells in phylactolaemates is mechanoreceptive. 


\section{Acknowledgments}

This study was performed as a part of a budget project No. AAAA-A17-1170301100293 at the Zoological Institute of the Russian Academy of Sciences, and supported by the Russian Foundation for Basic Research (project No. 15-29-02650).

\section{References}

Croll R., Jackson D., Voronezhskaya E. 1997. Catecholamine-containing cells in larval and postlarval bivalve molluscs // Biol. Bull. Vol.193. P.116-124.

Dyakonova V.E. 2012. [Neurotransmitter mechanisms of context-dependent behavior] // Zhurn. Vysshey Nervnoy Deyatelnosti. Vol.62. P.1-17 [in Russian, with English summary].

Fominykh M.Y. 1982. [Sensory nerve cells in epithelium and subepithelial connective tissue of trunk segments in polychaetes Nephthys hombergii and Harmothöe imbricata] // Zhurn. Evol. Biohim. Fiziol. Vol.8. No.5. P.507-513 [in Russian].

Hyman L.H. 1959. The invertebrates. 5. Smaller coelomate groups. McGraw-Hill. 783 p.

Kotikova E.A., Raikova O.I., Reuter M., Gustafsson M.K.S. 2002. The nervous and muscular systems in the freeliving flatworm Castrella truncata (Rhabdocoela): an immunocytochemical and phalloidin fluorescence study // Tissue and Cell. Vol.34. No.5. P.365-374.

Ovsyannikov V.I. 2003. [Neuromediators and hormones in intestine]. St. Petersburg. 134 p. [in Russian]

Schwaha T., Wanninger A. 2012. Myoanatomy and serotonergic nervous system of plumatellid and fredericellid phylactolaemata (Lophotrochozoa, Ectoprocta) // J. Morphol. Vol.273. No.1. P.57-67.

Schwaha T., Wanninger A. 2015. The serotonin-lir nervous system of the Bryozoa (Lophotrochozoa): a general pattern in the Gymnolaemata and implications for lophophore evolution of the phylum // BMC Evol. Biol. Vol.15. No.1:223. DOI 10.1186/s12862-0150508-9

Serova K.M., Vishnyakov A.E., Zaitseva O.V., Ostrovsky A.N. 2016. Distribution of serotonin and FMRFamide in the nervous system of different zooidal types of cheilostome Bryozoa: a case study of Arctonula arctica // Dokl. Biol. Sci. Vol.471. P.288-290.

Serova K.M., Vishnyakov A. E., Zaitseva O.V., Kotenko O.N., Ostrovsky A.N. 2017. Comparative analysis of nervous system structure of polymorphic zooids in marine bryozoans // Dokl. Biol. Sci. [in press]

Shunkina K.V., Starunov V.V., Zaitseva O.V., Ostrovsky A.N. 2013. Serotonin and FMRFamide immunoreactive elements in the nervous system of freshwater bryozoans (Bryozoa: Phylactolaemata) // Dokl. Biol. Sci. Vol. 451. P. 244-247.

Shunkina K.V., Starunov V.V., Zaitseva O.V., Ostrovsky A.N. 2014. Sensory elements and innervation in the freshwater bryozoan Cristatella mucedo lophophore // Dokl. Biol. Sci. Vol.455. P.125-128.

Shunkina K.V., Zaytseva O.V., Starunov V.V., Ostrovsky A.N. 2015. Comparative morphology of the nervous system in three phylactolaemate bryozoans // Front. Zool. DOI 10.1186/s12983-015-0112-2

Temereva E.N., Tsitrin E.B. 2014. Organisation and metamorphic remodeling of the nervous system in Phoronopsis harmeri larvae (Lophotrochozoa: Phoronida): new questions concerning the old problem of "lophophorates" phylogeny // Front. Zool. Vol.11. No.3.

Temereva E.N., Tsitrin E.B. 2015. Modern data on the innervation of the lophophore in Lingula anatina (Brachiopoda) support the monophyly of the Lophophorates // PLoS One. Vol.10. No.4.

Temereva E.N., Kosevich I.A. 2016. The nervous system of the lophophore in the ctenostome Amathia gracilis provides insight into the morphology of ancestral ectoproct and the monophyly of the lophophorates // BMC Evol. Biol.. Vol.16. No.181 DOI 10.1186/ s12862-016-0744-7

Zaitseva O.V., Markosova T.G., Smirnov R.V., Soboleva V.V. 2004. Investigation of cell composition of the intestinal nervous system in Gastropods, Nemertins and Priapulids // Proc. Zool. Inst. Russ. Acad. Sci. St. Petersburg. Vol.300. P.171-180.

Zaitseva O.V., Markosova I.M., Smirnov R.V. 2007. Monoamine- and peptide- containing elements in the body wall and nervous trunks of Nemerteans // Rus. J. Mar. Biol. Vol. 33. No.4. P.245-253.

Zaitseva O.V., Petrov S.A. 2013. Biogenic amines in the nervous system of Nemerteans // Doklady Biological Sciences, General Biology. Vol.451. P.228-230.

Zaitseva O.V., Shumeev A.N., Korshunova T.A., Martynov A.V. 2015. Heterochronies in the formation of the nervous and digestive systems in early postlarval development of Opisthobranch mollusks: organization of major organ systems of the arctic dorid Cadlina laevis // Biol. Bul. Vol.42. No.3. P.186-195.

Responsible editor E.N. Temereva 